\title{
Aktivitas Antiinflamasi Ekstrak Etanolik Daun Arbenan [Duchesnea indica (Jacks.) Focke]
}

\author{
Risda Waris $^{1 *}$, A. Mumtihanah Mursyid ${ }^{2}$ \\ ${ }^{1}$ Department of Pharmacognocy, Faculty of Pharmacy, Universitas Muslim Indonesia \\ ${ }^{2}$ Department of Pharmaseutical, Faculty of Pharmacy, Universitas Muslim Indonesia
}

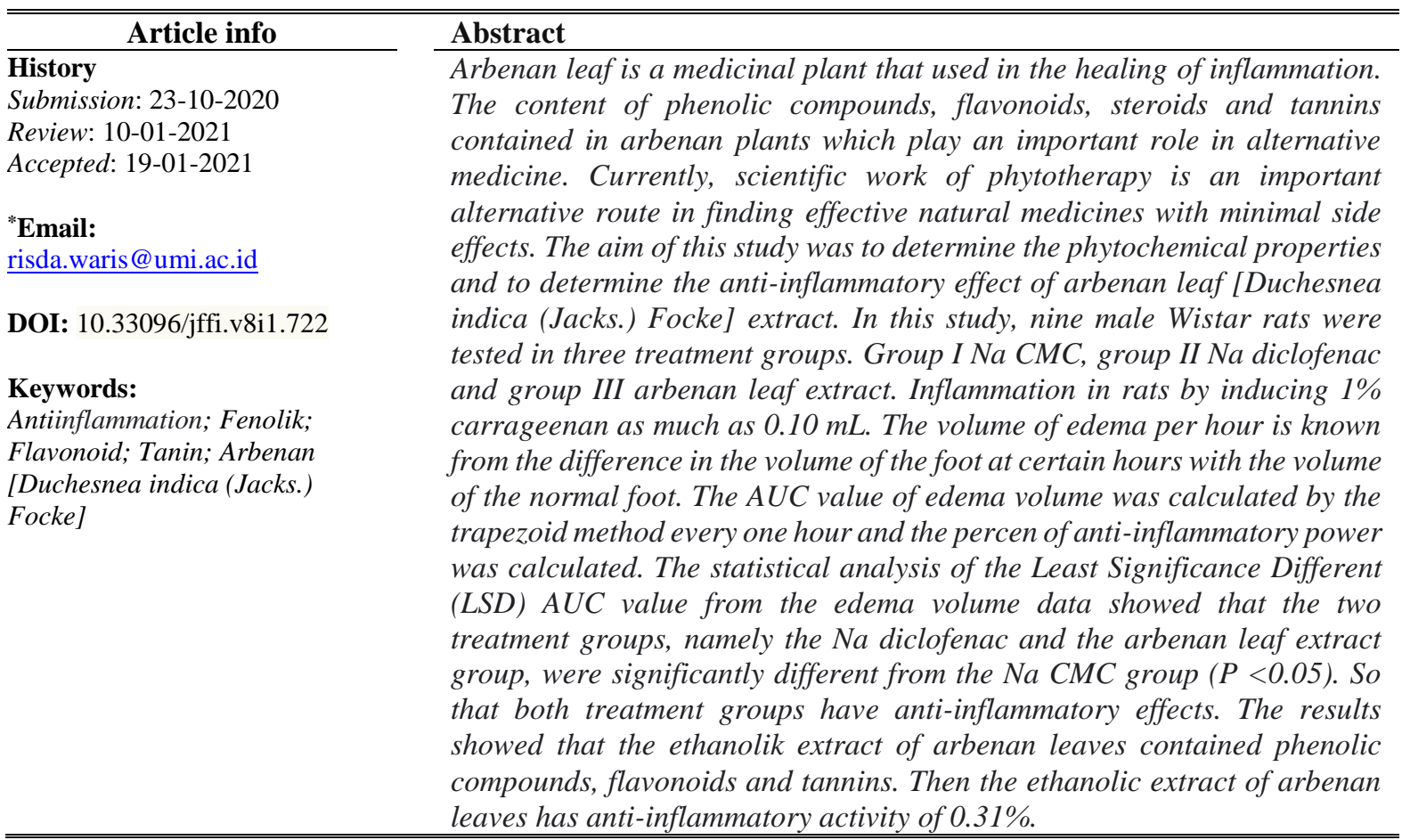

\section{Pendahuluan}

Pemanfaatan tumbuhan obat di indonesia merupakan langkah awal dalam memanfaatkan keanekaragaman hayati sebagai alternatif pengobatan yang lebih dipilih karena minim efek samping. Pemanfaatan obat dari alam telah banyak dilakukan sejak dahulu hingga saat ini masih dengan tujuan pencegahan dan pengobatan. Pengelolaan obat dari alam pun telah berkembang, oleh sebab itu pemanfaatan tumbuhan obat yang merupakan salah satu budaya bangsa selalu ditingkatkan menjadi obat tradisional melalui pengujian terhadap penemuan obat baru.

Berbagai penelitian mengenai pemanfaatan tanaman sebagai pengobatan telah banyak di laporkan, salah satunya tanaman arbenan yang dikenal dengan nama [Duchesnea indica (Jacks.) Focke] yang berasal dari family Rosaceae. Tanaman ini banyak tumbuh di berbagai negara dan ditemukan pula tumbuh liar di daerah pegunungan Malino \& Bawakareng Gowa Sulawesi Selatan. Meskipun masyarakat memanfaatkannya sebagai obat tradisional yang mampu menurunkan demam dan stimulan, menurut (Dalimarta, 2004) daun arbeban mampu mengurangi pembengkakan dan anti radang. Selain itu secara empiris telah digunakan sebagai obat tradisional untuk luka bakar.

Golongan senyawa yang terdapat dalam tanaman arbenan yaitu polifenol, triterpen, triterpen glikosida, glikosida, sterol dan flavonoid (Hui et al., 2012). Steroid bersifat sebagai anti inflamasi. Flavonoid memiliki aktivitas farmakologi sebagai anti inflamasi serta bersifat antioksidan dengan mengurangi ROS yang berlebihan, antibakteri dan dapat meningkatkan kontraksi luka dengan sifat antimikroba dan astringentnya (Kusumawardhani, Kalsum and Rini, 2015).

Penelitian penyembuhan radang merupakan salah satu hal yang sedang berkembang dan banyak dilakukan oleh para peneliti dan praktisi tradisional di seluruh dunia khususnya India dan Cina. Menurut World Health Organization (WHO), $80 \%$ populasi di Negara Asia dan Afrika menggunakan pengobatan tradisional. Pentingnya penanganan peradangan secara optimal telah mendorong berkembang pesatnya penelusuran tumbuhan obat baru dalam penelitian antiinflamasi di bidang farmasi.

Berdasarkan hal tersebut maka sangat penting untuk melakukan uji antiinflamasi tanaman arbenan [Duchesnea indica (Jacks.) Focke] untuk 
pengobatan inflamasi, sehingga dapat dimanfaatkan sebagai alternatif dalam pengobatan dalam lingkungan masyarakat.

\section{Metode Penelitian II.1 Alat dan Bahan}

Alat yang di gunakan adalah pletysmometer, maserator, jangka sorong, kompor listrik, Pisau bedah, pipa kapiler, pipet tetes, plat tetes, seperangkat alat gelas (pyrex) sedangkan bahan utama yang digunakan dalam penelitian adalah asam asetat anhidrat, aquadest, etanol $70 \%$, $\mathrm{FeCl}_{3}, \mathrm{HCl} 2 \mathrm{~N}, \mathrm{HCl} 1 \mathrm{M}$, nheksan, magnesium, $\mathrm{NaOH} 1 \mathrm{M}, \mathrm{n}$-heksan, pereaksi Dragendorf, pereaksi Mayer, pereaksi Wagner, pereaksi LiebermannBurchard, Serbuk Mg, kloroform, etanol $70 \%$, karagenan, tikus jantan (Rattus norvegicus), Na. CMC, Na. diklofenak, daun arbenan [Duchesnea indica (Jacks.) Focke] dan bioplasenton®.

\section{II.2 Pengambilan \& Pengolahan Sampel}

Sampel daun Arbenan [Duchesnea indica (Jacks.) Focke], diperoleh dari Malino, SulawesiSelatan. Sampel yang telah dikumpulkan dicuci lalu dilakukan sortasi basah kemudian dikeringkan lalu disortasi kering kemudian di rajang lalu diserbukkan dan dikumpulkan untuk proses ekstraksi (Pratiwi et al., 2019).

\section{II.3 Metode Ekstraksi}

Serbuk daun arbenan [Duchesnea indica (Jacks.) Focke] ditimbang sebanyak $100 \mathrm{~g}$, di maserasi dengan etanol $500 \mathrm{~mL}$, kemudian disaring hingga dihasilkan ekstrak cair dan residu. Proses maserasi dilakukan selama 3 x 24 jam, ekstrak cair yang diperoleh kemudian dipekatkan dengan alat Rotary Vacum Evaporator pada suhu $50{ }^{\circ} \mathrm{C}$ hingga diperoleh ekstrak kental (Najib, 2018).

\section{II.4 Identifikasi Golongan Senyawa}

Identifikasi kandungan kimia Berdasarkan Harborne yang dilakukan pada ekstrak etanol daun arbenan [Duchesnea indica (Jacks.) Focke] (Waris, 2016):

1. Uji Fenolik; Sebanyak $10 \mathrm{mg}$ ekstrak dilarutkan dengan $2 \mathrm{~mL}$ etanol $70 \%$ dan ditambahkan 3 tetes larutan $\mathrm{FeCl}_{3}$. Terbentuknya warna hitam kebiruan mengindikasikan adanya senyawa fenolik.

2. Uji Flavonoid; Sebanyak $2 \mathrm{~mL}$ ekstrak etanol ditambahkan serbuk $\mathrm{Mg}, 1 \mathrm{~mL} \mathrm{HCl} 2 \mathrm{M}$ dan 2 $\mathrm{mL}$ amilalkohol, dilakukan pengocokkan. Adanya perubahan warna larutan menjadi kuning menunjukkan adanya flavonoid.

3. Uji Alkaloid; Sebanyak $2 \mathrm{~mL}$ ekstrak etanol ditambahkan ammonia 25\% dan ditambahkan kloroform. Kemudian diekstraksi dengan $\mathrm{HCl}$ $10 \%$.

a) Pereaksi Mayer Lp (K-mercuri iodide), terbentuk endapan putih menggumpal menunjukkan adanya alkaloid b) Pereaksi Wagner Lp (Iodin dalam KI), terbentuk endapan menunjukkan adanya alkaloid

c) Pereaksi Dragendroff (K-Bismut Iodida), terbentuk endapan merah menunjukkan adanya alkaloid.

4. Uji Tritepenoid; Sebanyak $2 \mathrm{~mL}$ ekstrak etanol ditambahkan $2 \mathrm{~mL}$ n-heksana, dikocok. Lapisan n-heksana ditambahkan pereaksi LiebermannBurchard. Adanya perubahan warna menjadi merah menunjukkan adanya triterpenoid.

5. Uji Steroid; Sebanyak $2 \mathrm{~mL}$ ekstrak etanol ditambahkan $2 \mathrm{~mL}$ n-heksana, dikocok. Lapisan n-heksana ditambahkan pereaksi LiebermannBurchard. Adanya perubahan warna menjadi biru kehijauan menunjukkan adanya steroid.

6. Uji Tanin; Sebanyak $2 \mathrm{~mL}$ ekstrak etanol ditambahkan $2 \mathrm{~mL} \mathrm{FeCl3} \mathrm{1 \% ,} \mathrm{kemudian}$ dilakukan pengocokkan. Adanya perubahan warna larutan menjadi coklat kehitaman menunjukkan adanya tanin.

\section{II.5 Uji Aktivitas Antiinflamasi}

Hewan coba yang digunakan sebanyak sembilan ekor tikus jantan galur wistar dibagi menjadi tiga kelompok percobaan. Hewan coba diadaptasi selama 1 pekan. Hewan coba dipuasakan selama 18 jam tetapi tetap diberi minum. Pada hari pengujian, hewan coba ditimbang dan dikelompokkan secara acak, yaitu kelompok kontrol negatif, kelompok kontrol positif dan kelompok uji ekstrak daun arbenan.

Masing-masing kelompok pengujian terdiri dari 3 ekor. Setiap tikus diberi tanda batas pada sendi kaki belakang tikus agar pada saat pengukuran menggunakan pletismometer selalu sama. Sebelum melakukan perlakuan, volume kaki tikus diukur untuk mengetahui volume awal (Vo) dengan cara mencelupkan ke dalam pletysmometer.

Kemudian hewan coba diinduksi dengan karagenan $1 \%$ sebanyak $0,2 \mathrm{~mL}$. Selanjutnya diberi perlakuan secara peroral menggunakan sonde pada jam ketiga setelah penginduksian. Tikus pada masing-masing kelompok diberi perlakuan sebagai berikut:

a) Kelompok 1 (kontrol negatif) diberikan $\mathrm{Na}$. CMC $1 \%$.

b) Kelompok 2 (kontrol positif) diberikan natrium diklofenak $25 \mathrm{mg} / \mathrm{KgBB}$.

c) Kelompok 3 diberikan ekstrak etanol 100 $\mathrm{mg} / \mathrm{KgBB}$. Volume udem telapak kaki tikus diukur menggunakan pletysmometer setiap 1 jam selama 15 jam setelah diinduksi karagenan $1 \%$.

\section{Hasil dan Pembahasan}

Saat ini, fitoterapi hasil karya ilmiah menjadi salah satu jalur alternatif penting dalam menemukan obat-obatan alami yang efektif dengan minim efek samping. Tujuan penelitian ini adalah 
untuk menentukan sifat fitokimia dan menentukan efek antiinflamasi dari ekstrak daun arbenan [Duchesnea indica (Jacks.) Focke].

Penarikan senyawa-senyawa kimia yang terkandung dalam suatu tumbuhan dilakukan menggunakan metode ekstraksi. Pada penelitian ini metode ekstraksi yang digunakan yaitu maserasi. Metode ini dipilih karena maserasi merupakan metode ekstraksi dingin yang tidak merusak komponen kimia dari masing-masing sampel daun arbenan [Duchesnea indica (Jacks.) Focke]. Pelarut yang digunakan untuk ekstraksi sampel daun arbenan [Duchesnea indica (Jacks.) Focke] yaitu etanol $70 \%$ karena dapat melarutkan senyawa polar maupun senyawa nonpolar.

Tabel 1. Hasil identifikasi kandungan kimia dari Daun Arbenan

\begin{tabular}{ccc}
\hline No & Identifikasi Fitokimia & Hasil Identifikasi fitokimia \\
\hline 1. & Fenolik & + \\
2. & Flavonoid & + \\
3. & Alkaloid & - \\
4. & Triterpenoid & - \\
5. & Steroid & - \\
6. & Tanin & + \\
\hline
\end{tabular}

Identifikasi kandungan fitokimia pada ekstrak daun arbenan memberikan hasil positif pada uji kandungan Fenolik, flavonoid, steroid, dan tanin (Tabel 1). Senyawa Flavonoid mengalami reduksi oleh $\mathrm{Mg} \& \mathrm{HCl}$ sehingga menghasilkan warnah kekuningan, Tujuan penambahan logam $\mathrm{Mg}$ dan $\mathrm{HCl}$ adalah untuk mereduksi inti benzopiron yang terdapat dalam struktur flavonoid sehingga terbentuk garam flavilium berwarna merah kekuningan atau jingga Flavonoid memiliki dua cincin aromatik dengan gugus hidroksil lebih dari satu (Ergina, Nuryanti and puspitasari, 2014). Warna yang terbentuk pada saat pengujian yaitu kuning pudar, hal ini kemungkinan disebabakan karena kandungan flavonoidnya memiliki persentase yang kecil. Seperti yang telah di laporkan pada beberapa hasil study bahwa keragaman genetik dan variasi biologis, lingkungan, musiman dan tahun ke tahun secara signifikan mempengaruhi kandungan flavonoid pada suatu tanaman (Kumar and Roy, 2018). Senyawa fenol dengan gugus hidroksil semakin banyak memiliki tingkat kelarutan dalam air semakin besar atau bersifat polar, sehingga dapat terekstrak dalam pelarutpelarut polar (Robinson, 1995). Hasil identifikasi lainnya menunjukkan positif mengandung tanin menggunakan $\mathrm{FeCl}_{3}$ untuk menentukan apakah sampel mengandung gugus fenol. Terdapat empat senyawa fenolik dalam Duchesnea indica (Jacks.) Focke yaitu gigis fenolik, ellagitanin, ellagic acid dan glikosida ellagic acid (Zhu, Dong and Guo, 2015). Adanya gugus fenol ditunjukkan dengan warna coklat kehitaman atau biru tua setelah ditambahkan dengan $\mathrm{FeCl}_{3}$, Terbentuknya warna coklat kehitaman atau biru tinta pada ekstrak setelah ditambahkan dengan $\mathrm{FeCl}_{3}$ karena tanin akan membentuk senyawa kompleks dengan ion $\mathrm{Fe}_{3}+$ (Harborne, 1987) Golongan senyawa polifenol memungkinkan menangkap radikal bebas berbahaya seperti super oksidan dan radikal hidroksil (Nuraziza, Seniwati and Waris, 2017). Efek flavonoid sebagai antioksidan secara tidak langsung juga mendukung efek antiinflamasi flavonoid (Apridamayanti, Sanera and Robiyanto, 2018). Adanya radikal bebas dapat menarik berbagai mediator inflamasi (Nijveldt et al., 2001).

Uji aktivitas antiinflamasi dilakukan dengan menggunakan metode edema kaki hewan uji, dengan menggunakan alat pengukur volume kaki pada hewan uji yaitu plestimometer yang diisi dengan air raksa. Pengukuran volume radang yang menggunakan alat pletismometer yang memiliki prinsip berdasarkan hukum Archimedes.

Berdasarkan hasil yang diperoleh pada grafik volume edeme (Gambar 1) menunjukkan bahwa volume edema pada kontrol negatif merupakan volume yang paling besar dibandingkan dengan kelompok kontrol positif dan kelompok ekstrak daun arbenan. Grafik tersebut menunjukkan kenaikan volume edema dari jam ke dua sampai jam ke empat. Kemudian untuk kelompok ekstrak daun arbenan hanya meningkat pada jam ke tiga saja. Peningkatan volume edema ini diakibatkan oleh adanya pelepasan mediator-mediator inflamasi pada jaringan setelah diinduksi karagenan. 


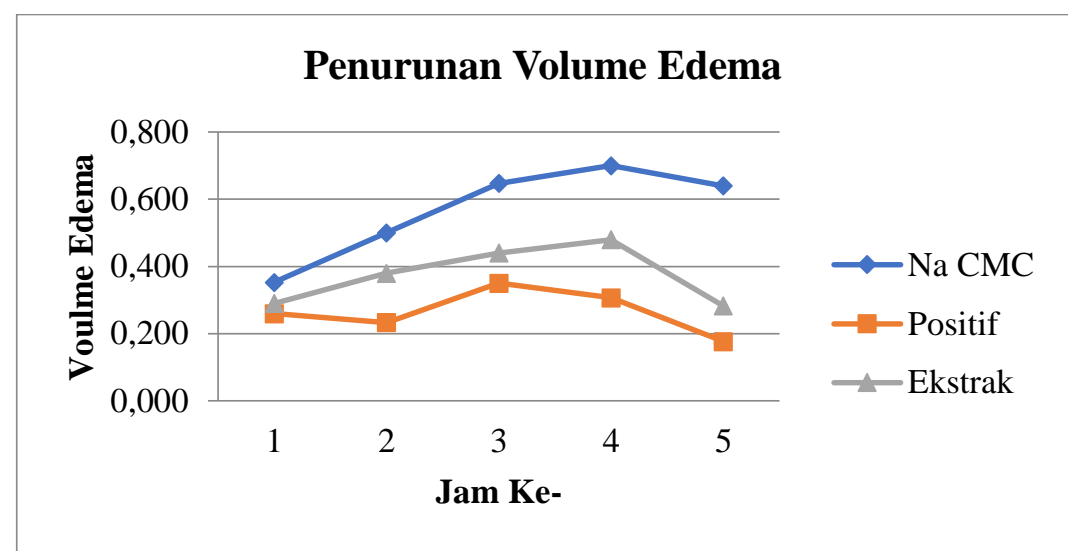

Gambar 1. Grafik volume edema pada kaki tikus seluruh kelompok perlakuan

Penurunan volume edema pada kelompok kontrol positif pada jam ke-4 \& ke-5, lalu pada kelompok ekstrak daun arbenan pada jam ke-5, karena pada kedua kelompok hewan uji ini terjadi penghambatan sintesis prostaglandin ke jaringan. Sedangkan pada kelompok kontrol negatif tetap ada terjadi penghambatan pelepasan prostaglandin ke jaringan tetapi tidak setinggi dibandingkan kelompok uji. Sehingga kelompok yang dapat memberikan efek antiinflamsi adalah kelompok kontrol positif, lalu kelompok ekstrak daun arbenan sedangkan pada kelompok kontrol negatif tidak memberikan efek tersebut.
Hasil penelitian volume edema selanjutnya di gunakan untuk memperoleh nilai AUC yang dapat memberikan informasi efektifitas dari dai ekstrak daun arbenan untuk menurunkan radang pada hewan coba. Berdasarkan data pada Tabel 2. diketahui bahwa nilai AUC terbesar adalah kontrol negatif $\mathrm{Na}$ CMC sedangkan nilai AUC paling kecil yaitu kontrol positif Na diklofenak, sementara kelompok ekstrak daun erbenan memiliki nilai AUC di tengah. Hal ini menunjukkan bahwa kontrol positif na diklofenak dan kelompok ekstrak daun arbenan memiliki efek sebagai obat antiinflamasi.

Tabel 2. Hasil pengujian efektifitas antiinflamasi ekstrak daun arbenan

\begin{tabular}{|c|c|c|c|c|c|c|c|}
\hline \multirow{2}{*}{$\begin{array}{l}\text { Kelompok } \\
\text { Perlakuan }\end{array}$} & \multicolumn{5}{|c|}{ \% Volume Edema } & \multirow{2}{*}{$\begin{array}{c}\text { AUC Total } \\
\text { (ml.jam) }\end{array}$} & \multirow{2}{*}{$\begin{array}{c}\% \\
\text { DAI }\end{array}$} \\
\hline & 1 & 2 & 3 & 4 & 5 & & \\
\hline $\mathrm{Na}-\mathrm{CMC} 1 \%$ & $1,455 \pm 0,151$ & $2,019 \pm 0,694$ & $2,702 \pm 0,737$ & $2,930 \pm 0,966$ & $2,690 \pm 0,911$ & $2,52 \pm 0,386^{b}$ & 0,0 \\
\hline $\begin{array}{l}\text { Na diklofenak } \\
25 \mathrm{mg}\end{array}$ & $1,073 \pm 0,131$ & $0,962 \pm 0,255$ & $1,446 \pm 0,254$ & $1,259 \pm 0,050$ & $0,734 \pm 0,232$ & $1,24 \pm 0,110^{\mathrm{a}}$ & 0,51 \\
\hline $\begin{array}{l}\text { Ekstrak arbenan } \\
1 \%\end{array}$ & $1,246 \pm 0,076$ & $1,628 \pm 0,100$ & $1,892 \pm 0,420$ & $2,054 \pm 0,274$ & $1,214 \pm 0,035$ & $1,73 \pm 0,150^{\mathrm{a}}$ & 0,31 \\
\hline
\end{tabular}

Nilai AUC yang telah diperoleh dilakukan uji statistik, agar dapat mengetahui data yang berbeda signifikan antar kelompok. Hasil analisis statistik data AUC tiap kelompok melalui tes normalitas dan homogenitas yaitu $\mathrm{P}>0,05$, artinya data tersebut telah terdistribusi normal dan homogen. Setelah diperoleh data tersebut normal dan homogen maka dilanjutkan dengan uji One Way ANOVA yaitu uji LSD dengan taraf kepercayaan $95 \%$.

Berdasarkan hasil uji LSD nilai AUC tersebut menunjukkan bahwa kedua kelompok perlakuan berbeda bermakna terhadap kontrol negatif $(\mathrm{P}<0,05)$. Sehingga kedua kelompok perlakuan memiliki efek antiinflamasi. kontrol positif Na diklofenak dan ekstrak daun arbenan $1 \%$ berbeda bermakna dengan kontrol negatif $(\mathrm{P}<0,05)$.

Kemudian Hasil dari Nilai AUC yang diperoleh dari data volume edema, dapat digunakan untuk menghitung persentase daya antiinflamasi (DAI). Tabel diatas menunjukkan hasil perhitungan persentase DAI yang berarti semakin besar persen DAI maka semakin besar aktivitas antiinflamasinya. Persen DAI berbanding terbalik dengan nilai AUC, apabila nilai AUC tinggi maka persen DAI rendah begitu juga sebaliknya. Berdasarkan data hasil perhitungan persen DAI bahwa kelompok ekstrak daun arbenan 0,31\% mendekati kontrol positif $\mathrm{Na}$ diklofenak dengan nilai $0,51 \%$. Sehingga kelompok perlakuan ekstrak daun arbenan efektif menghambat radang.

Aktivitas antiinflamasi dari ekstrak daun arbenan di duga karena kandungan flavonoid dan tanin, meskipun dalam persentase yang sedikit namun laporan (Amarowicz, 2007), bahwa senyawa fenolik, tanin dan flavonoid memiliki beberapa efek biologis, termasuk antioksidan dan antiinflamasi. Hasil penelitian (Lei et al., 2008) Zhao L et all,2008 
bahwa ekstrak Duchesnea indica menekan sitokin dan mediator pro-inflamasi dengan memblokir aktivasi NF-kB sebagai efek antiinflamasi Serta meningkatkan produksi HO-1 mengurangi peradangan.

\section{Kesimpulan}

Ekstrak etanolik daun arbenan [Duchesnea indica (Jacks.) Focke] memiliki aktivitas antiinflamasi dengan daya aktivitas antiinflamasi sebesar $0,31 \%$.

\section{Kesimpulan}

Rektor Universitas Muslim Indonesia (UMI) serta Lembaga Penelitian dan Pengembangan Sumberdaya LP2S UMI melalui hibah penelitian dosen internal tahun 2020.

\section{Daftar Pustaka}

Amarowicz, R. (2007) 'Tannins: the new natural antioxidants?', European Journal of Lipid Science and Technology, 109(6), pp. 549551. doi: 10.1002/ejlt.200700145.

Apridamayanti, P., Sanera, F. \& Robiyanto, R. (2018) 'Aktivitas Antiinflamasi Ekstrak Etanol Daun Karas (Aquilaria malaccensis Lamk.)', Pharmaceutical Sciences and Research, 5(3), pp. 152-158.

Dalimarta, S. (2004) Atlas Tumbuhan Obat Indonesia. 3rd edn. Jakarta: Puspaswara.

Ergina, Nuryanti, S. \& puspitasari, I. D. (2014) 'Qualitative test of Secondary Metabolistes Compounds in palado leaves (Agave angustifolia) extracted with water and ethanol', Jurnal Akademika Kimia, 3(3).

Hui, J. X. Qiang, G.J. Wen, S.C. \& Liu, X.M. (2012) 'High frequency shoot organogenesis in juvenile leaf of Duchesnea indica (Andr.) Focke', African Journal Of Biotechnology, 11(17), pp. 4039-4044. doi: 10.5897/AJB11.3116.

Kumar, V. \& Roy, B. K. (2018) 'Population authentication of the traditional medicinal plant Cassia tora L. based on ISSR markers and FTIR analysis', Scientific Reports, 8(1), p. 10714. doi: 10.1038/s41598-01829114-1.

Kusumawardhani, A. D., Kalsum, U. \& Rini, I. S. (2015) 'Pengaruh Sediaan Salep Ekstrak Daun Sirih (Piper betle Linn.) terhadap Jumlah Fibroblas Luka Bakar Derajat IIA pada Tikus Putih (Rattus norvegicus) Galur Wistar', 2, p. 13.

Lallo, S. Hardianti, B. Umar, H. Trisurani, W. Wahyuni, A. \& Latifa, M. (2020) 'Aktivitas Anti Inflamasi dan Penyembuhan Luka dari Ekstrak Kulit Batang Murbei (Morus alba L.): Anti-inflammatory and Wound Healing Activities of Mulberry Barks (Morus alba L.) Extract', Jurnal Farmasi Galenika (Galenika Journal of Pharmacy)
(e-Journal), 6(1), pp. 26-36. doi: 10.22487/j24428744.2020.v6.i1.14661.

Lei, Z. Zhang, S.L. Tao, J.Y. Jin, F. Pang, R. Guo, Y. J. Ye. P. Dong, J.H. \& Zheng, G.H. (2008) 'Anti-Inflammatory Mechanism of a Folk Herbal Medicine, Duchesnea indica (Andr) Focke at RAW264.7 Cell Line', Immunological Investigations, 37(4), pp. 339-357. doi: 10.1080/08820130802111589.

Najib, A. (2018) Ekstraksi Senyawa Bahan Alam. Yogyakarta: Deepublish.

Nijveldt, R. Nood, E. Horn, ECP. Boelens, G. Norren, K. \& Leeuwen PAM.. (2001) 'Flavonoids: a review of probable mechanisms of action and potential applications', Am Soc Clin Nutr, pp. 48-25.

Nuraziza, Seniwati \& Waris, R. (2017) 'Uji Aktivitas Antioksidan Ekstrak Etanol Daun Arbenan (Duchesnea indica (Jacks.) Focke) Dengan Metode Dpph', As-Sifaa, 09(02), pp. 154-164.

Pratiwi, D. I. Syarif, R. A. Waris, R. \& Faradiba. (2019) 'Isolasi Senyawa Antioksidan Ekstrak Metanol Kulit Buah Naga Merah (Hylocereus polyrhizus)', Jurnal Fitofarmaka Indonesia, 6(1), pp. 340-346. doi: 10.33096/jffi.v6i1.466.

Waris, R., Pratiwi, E. D. \& Najib, A. (2016) 'Radical Scavenging Activity of Leaf Extract of Edible Hibiscus (Abelmoschus manihot L.)', International Journal of PharmTech Research, 9(6), pp. 343-347.

Zhu, M., Dong, X. \& Guo, M. (2015) 'Phenolic Profiling of Duchesnea indica Combining Macroporous Resin Chromatography (MRC) with HPLC-ESI-MS/MS and ESIIT-MS', Molecules, 20(12), pp. 2246322475. doi: 10.3390/molecules201219859. 